\title{
Seven Challenges in Conceptualizing and Assessing Entrepreneurial Skills or Mindsets in Engineering Entrepreneurship Education
}

\author{
Constanza Miranda ${ }^{1,2, *(D)}$, Julian Goñi ${ }^{2}\left(\mathbb{D}\right.$, Bruk Berhane $^{3}$ and Adam Carberry ${ }^{4}(\mathbb{D}$ \\ 1 Biomedical Engineering Department, Johns Hopkins University, Baltimore, MD 21218, USA \\ 2 DILAB School of Engineering, Pontificia Universidad Católica de Chile, Santiago 7820436, Chile; \\ jvgoni@uc.cl \\ 3 SUCCEED, Florida International University, Miami, FL 33174, USA; bberhane@fiu.edu \\ 4 The Polytechnic School, Arizona State University, Tempe, AZ 85212, USA; Adam.Carberry@asu.edu \\ * Correspondence: csmirand@uc.cl
}

Received: 18 September 2020; Accepted: 27 October 2020; Published: 30 October 2020

\begin{abstract}
The growth of undergraduate entrepreneurship education programs and research, both within and outside of business programs, has led to a diverse array of academic literature on this topic. The diversity of perspectives has led to many conceptual and educational challenges that remain unresolved within the literature. The following conceptual paper offers a critical perspective on challenges that have been identified. A narrative-style literature review was conducted to explore challenges emerging from both (a) the practice of teaching entrepreneurship and (b) the definitions and assessment of entrepreneurial mindsets and skills that result from those education processes in entrepreneurship education, particularly within an undergraduate engineering education context. We achieve this objective by discussing previously dispersed sources of literature from disciplines that have critically discussed and explored entrepreneurial themes, such as business education, sociology, psychology, and philosophy. Contemporary debates within multiple disciplines are integrated and organized as challenges to inspire new theoretical discussions among scholars, educators, and other practitioners that can inform a more comprehensive way to conceive and assess entrepreneurship in engineering education. Seven challenges were identified ranging from the definition of entrepreneurship in education to the role of ethics in the teaching and assessment of entrepreneurship. We use these seven challenges and research questions as a starting point for the disambiguation of the working definition of entrepreneurship in the context of engineering education.
\end{abstract}

Keywords: entrepreneurship; entrepreneurship education; engineering education; engineering entrepreneurship; entrepreneurial mindset

\section{Introduction}

Engineering schools have recently increased their efforts in entrepreneurship due in part to accreditation criteria, local demands related to public policies [1] and known benefits for national economies [2]. The growth experienced in engineering education (e.g., entrepreneurship-related instruction and publications) has even surpassed that which has occurred within business programs [3-6]. This shift in the curriculum is yet another change to what has been done traditionally dating back to the Grinter report [7], which introduced engineering design after students had obtained a strong foundation in the sciences and mathematics [8]. This change is among many global shifts in engineering education over the last few decades that have elevated professional skills and active learning. 
Changes to what is now emphasized in engineering curricula is also due in part to the Engineering Criteria (EC) 2000 implemented by Accreditation Board for Engineering and Technology (ABET) in 1997, which introduced an outcomes-based approach for evaluating engineering programs [9]. ABET now accredits 4144 programs at 812 colleges and universities in 32 countries [10], all of which are required to assess student outcomes. Studies on the implementation of such curricula provide evidence for how instructors have integrated industrial needs into course assessments [11,12] including the incorporation of skills required to be successful in smaller companies like startups (e.g., going beyond minimum expectations, or exhibiting incredulity towards existing solutions) [12].

The growth in entrepreneurship inside engineering education has been fostered by changes to ABET and active involvement of communities and institutions all around the world [3]. Changes are occurring, as demonstrated by the increase in academic literature on entrepreneurship education over the last decade [13] In the United States, organizations such as VentureWell (formerly the National Collegiate Inventors and Innovators Alliance) launched by the Lemelson Foundation; and The Kern Entrepreneurial Engineering Network (KEEN) have funded programs and initiatives for many engineering colleges. Associated efforts have had the opportunity to disseminate their work through conferences (e.g., Stanford's Roundtable on Entrepreneurship Education or the Research in Engineering Education Symposium (REES)), society divisions (e.g., Entrepreneurship and Innovation Division of the American Society for Engineering Education (ASEE)), and journal publications (e.g., the 2020 special issue published by Entrepreneurship Education and Pedagogy; [6]). In Latin America, particularly in Chile, the 2012 government initiative "Nueva Ingeniería 2030" (New Engineering 2030) has provided direct funding to universities in order to support their efforts to promote applied research, technological development, innovation, and entrepreneurship into their curricula and campuses [14]. In Europe, the Entrepreneurship 2020 Action Plan [15] developed a blueprint for entrepreneurship education that expands on the need of technology-based entrepreneurship education.

Goals related to becoming more entrepreneurial have placed considerable pressure on higher education institutions around the world to generate educational programs that foster the development of entrepreneurial skills and mindsets in students [16]. More than half of the engineering programs accredited by ABET in 2018 offered entrepreneurship education options [17]. The ways in which entrepreneurial education has been introduced varies from program to program and are usually included under the broad category of "entrepreneurship education". The premise that entrepreneurship can be taught and learned [16] has led to more than 3000 programs on entrepreneurship education around the world [18].

Entrepreneurship within the context of engineering learning has been presented as the attainment of entrepreneurial knowledge, entrepreneurial mindset, entrepreneurial skills (e.g., the ability to lead, address real world issues, effectively communicate, react or adapt in the face of uncertainty, and deal with risk and failure), and/or entrepreneurial attitudes [19-21]. The actual structure and objectives of those curricula are still not institutionalized across ABET engineering programs [22]. This is the case despite the fact that current ABET accreditation guidelines strongly parallel those of entrepreneurship education [19]. The lack of explicit entrepreneurship referencing and the relatively large number of ABET engineering programs offering some variation of entrepreneurship coursework suggests the need for a common framework for evaluating and defining entrepreneurship-related course objectives [12]. Such an effort should begin by considering currently existing frameworks, such as the Three C's guiding the Kern Entrepreneurship Education Network (KEEN).

This paper offers a critical perspective on entrepreneurial learning in the context of engineering education. The following sections of this conceptual paper discuss some of the major challenges that emerge when attempting to broadly explain the body of literature within this space. This effort attempts to categorize these challenges into different thematic areas. It does not seek to exhaust all topics, but rather, to map the most salient themes to guide future discussions and to provide an overview for researchers, scholars, and practitioners in the field. The paper presents seven challenges that have emerged from a narrative style review of the literature [23]. In particular, this article seeks to explore 
challenges emerging from both (a) the practice of teaching entrepreneurship and (b) the definitions and assessment of entrepreneurial mindsets and skills that result from those education processes.

These emergent challenges are: $01 . \quad$ The economic reification of entrepreneurship; 02. Entrepreneurship, to be or not to be; 03 . The decontextualization of entrepreneurship; 04 . The domain specificity of entrepreneurship; 05. Entrepreneurship and educational theory; 06. Loss of specificity and assessment in entrepreneurship; 07. A value-driven entrepreneurship in research and practice.

\section{Materials and Methods}

As a team, we had been present in several discussions held at the entrepreneurship division of the American Society for Engineering Education Annual Conference and Exhibition (ASEE) and the Research Engineering Education Symposium (REES). In those discussions, the ambiguity in assessing and defining entrepreneurship in engineering education seemed to be a common appreciation among the attendees. In addition, at our own institutions, we had similar conversations with administrators and coordinators of entrepreneurship-based courses.

These inductive conversations had at conferences and locally within engineering programs are consistent with the current perception that engineering entrepreneurship education requires more research and discussions regarding its pedagogical, learning and philosophical underpinnings [24,25]. The following questions guide the presented work:

1. How can we establish a new way of seeing entrepreneurship learning in engineering?

2. How can we address entrepreneurship learning in engineering from a more theoretical point of view?

We address these questions by first understanding what were the theoretical dialogues taking place in academia regarding the field. A narrative literature review was conducted [23,26], which used secondary data to identify gaps in entrepreneurship education and its learning outcomes (e.g., entrepreneurial mindsets and skills). This article does not involve empirical work for raising data in the field. The review conducted looked to synthesize and package knowledge in a list of emerging challenges considering the rapid rate of publications [23].

We opted to define keywords related to major debates and previous research involved in entrepreneurship studies. These keywords included entrepreneurial education, entrepreneurial mindset, entrepreneurial cognition, entrepreneurial skills, engineering entrepreneurship education, and engineering entrepreneurship. This searching strategy allowed us to explore both entrepreneurship and engineering entrepreneurship literature. The criteria for inclusion and exclusion of studies were determined by the abstract and date of publication. Articles whose abstract indicated a discussion around the definitions and/or components of entrepreneurship were included. Exclusion criteria involved articles with no clear conceptual discussion of entrepreneurship's definition and/or delimitation both as an education practice or a learning outcome. Publications from the last ten years were included as well as other seminal or classic articles. We limited our search of literature to Web of Science, SCOPUS, and EBSCO indexed journals. Additional searching was conducted following the identification of the seven emergent challenges. This focused search was implemented to complement and expand on respective themes by revising additional sources in entrepreneurship education as well as other social sciences publications. Each challenge was first identified and described before exploring its implications for engineering entrepreneurship education.

\section{Results}

\subsection{Challenge 01: The Economic Reification of Entrepreneurship}

Assessment of entrepreneurship education usually focuses on identifying entrepreneurial intentionality [27]. Entrepreneurial intentionality has historically been defined as a "state of mind that directs and guides the actions of the entrepreneur towards the development and implementation of 
the business concept" (p. 64) [28]. This definition may be reductionist in scope, since more modern concepts like entrepreneurial mindset and cognitive processes have broader implications than only creating businesses [29]. This issue is related to what Anderson [30] calls the "economic reification" of entrepreneurship and constitutes a major challenge in entrepreneurship education.

According to Anderson [30], there is a need to generate a broader concept of entrepreneurship. The more human and complex dimensions of entrepreneurship (e.g., initiative, charisma, tenacity, management of uncertainty, and the struggle to gain acceptance of new ideas) cannot be explained simply by the act of business creation [30]. Many scholars have recently proposed new metaphors and definitions of entrepreneurship with a wider scope [31]. These definitions include social creativity in everyday life [32], association with a specific problem-solving method [33], and the incorporation of a science of the imagination [34]. Most of these alternative conceptualizations have tried to expand the concept of entrepreneurship to include the notion of the mindset intertwined with cognitive processes and skills. Ultimately, as Günzel-Jensen et al. [35] assert: "entrepreneurial skills and abilities are important to all citizens regardless of context. This is due to the fact that today's society has progressively become characterized by constant change and uncertainty" (p. 320).

The issue that Anderson [30] refers to is pervasive in the field of engineering education. Engineering entrepreneurship education has mostly been presented within the context of business-creation [4]. As described in the literature review conducted by Da Silva, Costa and De Barros [36], most of the academic work in education has focused either on business or teaching related themes (e.g., course and program structures) around entrepreneurship. It seems there is not yet a consensus around a notion that can incorporate the complexity of entrepreneurship with the cognitive processes related to the field of engineering education.

\subsection{Challenge 02: Entrepreneurship, To Be or Not To Be}

Some definitions used to define entrepreneurial skills and mindset in non-business oriented contexts have separated individuals who possess the entrepreneurial mindset from those one who lack it. Davis, Hall and Mayer [37] refer to the entrepreneurial mindset as "the constellation of motives, skills, and thought processes that distinguish entrepreneurs from non-entrepreneurs and that contribute to entrepreneurial success" (p. 22). This definition implies that you either have an entrepreneurial mindset or you do not. Assessment methods used in engineering education have suggested that the "entrepreneurial engineer" is supposed to have the right entrepreneurial skills, knowledge and attitudes in their industrial roles [38]. This notion of an entrepreneurial engineer seems to imply that there are some other segments that are not necessarily entrepreneurial and are openly considered "just" engineers [39].

This reductionist scope makes being entrepreneurial a binary category with no room for people who may fall somewhere in between the two extremes. These definitions can create social distinctions in how students are perceived or classified [40]. For example, an engineering student can exhibit entrepreneurial minded behaviors by solving a calculus homework problem in three different ways, or by designing multiple versions of a cellular phone that serve diverse audiences (e.g., veterans with disabilities). That same student may not act particularly entrepreneurially in other subjects or contexts. It is our assertion that the motives, skills, and thought processes of being entrepreneurial are social activities shared within a culture, but can be different in the form and intensity in which they manifest in a given time and context. This notion would suggest that institutions of higher education look to promote the entrepreneurial mindset in all individuals with an expectation for diversity of outcomes.

Skills in entrepreneurship include tendencies like adaptability or a capacity "to sense and adapt to uncertainty" (p.218) [29].Every student should benefit from programs that cultivate the capacity to be dynamic, flexible and self-regulating [29]. This is consistent with the assertion of Bosman and Fernhaber [41] that "are you an entrepreneur" is the wrong question. The appropriate question should be, "how entrepreneurial are you?" (p.11) [41]. 


\subsection{Challenge 03: The Decontextualization of Entrepreneurship}

Research on entrepreneurship has been mostly decontextualized throughout history [42] and has often been framed as "atomized, rational choice conceptualizations of entrepreneurs" (p.1215) [43], i.e., the homo entrepreneurus model. The entrepreneur depicted by this model is a lonely hero, under-emphasizing the role of collaboration and teaming [44]. It is only recently that there have been efforts to provide a more situated or contextualized model of research $[45,46]$. For example, Welter $[42,46]$ proposes that researchers should contextualize entrepreneurial research by paying attention to the social, spatial, and institutional context. Entrepreneurship scholars have typically focused on understanding how Western cultures and males apply and enact entrepreneurship and the entrepreneurial mindset/skills using gender and location as control variables [42]. Adding context would allow scholars to ask the "when, who, and where" of entrepreneurship and the entrepreneurial mindset.

Contextualization is relevant within educational settings because entrepreneurial learning involves transactions between the individuals and the local environment [47]. As Walter and Dohse [47] argue, some geographical regions and historical moments may provide better or worse conditions for learning to take place. At the meso and micro level, context also provides affordances, restrictions, and mediation for entrepreneurial learning processes [48]. A systematic literature review to explore how context is conceptualized and assessed in entrepreneurship education studies suggests that "context is everywhere and nowhere" within entrepreneurship education studies [49]. Studies including contextual elements have increased during recent years, but their use of context has been unsystematic and mostly anecdotal [49]. An ecological approach to human cognition [50] supports the idea of contextualizing constructs at a systemic level: first, in regard to the microsystems, i.e., educational institutions; second, within exosystems, i.e., engineering undergraduate institutions in general; and finally, within the macrosystem, i.e., national/international, larger societal/cultural settings.

The discussion on the decontextualization of entrepreneurship resonates with the literature on extended cognition. Contemporary philosophers argue that "cognitive processes are not located exclusively inside the skin of cognizing organisms" (p.22) [51]. This is what scholars have called the extended mind thesis [52] or the situated cognition thesis [53]. The human mind is not encapsulated in the brain and goes beyond and into the artifacts with which we interact. Dew et al. [54] advocate for the adoption of the situated mind thesis in entrepreneurship studies. Some studies have situated and extended mind explanations and arguments implicitly throughout the academic history of entrepreneurial cognition studies [55]. There is a question of whether such studies need to be more explicit.

The challenge posed for scholars in the field of engineering entrepreneurship education is to conceptualize context and embed it in the epistemology. The relationship between knowledge and context in the study of entrepreneurship needs to be explicit and further discussed. Researchers should conceptualize the implications of context in their assumptions, findings, methodologies, assessment methods, and conclusions in order to generate more context-conscious engineering entrepreneurship scholarship.

\subsection{Challenge 04: The Domain Specificity of Entrepreneurship}

The study and practice of entrepreneurship has expanded in recent years well beyond its origin in business schools [56]. Entrepreneurship studies have expanded in diverse fields such as engineering, medicine/healthcare, science, arts/music, design, and architecture [56]. This diversity provides great opportunities for cross-fertilization of the different forms of entrepreneurship education and practice, but also introduces challenging questions regarding the disciplinary nature (or lack thereof) of entrepreneurship.

This challenge has also been faced in other fields of study. For instance, Kaufman [57] has done an extensive review on research related to creativity and has devoted considerable attention to exploring whether creativity is more of a discipline-specific or a generalizable form of human cognition. We could question whether entrepreneurship is a discipline-bound form of cognition. 
Nadelson et al. [58] describe the entrepreneurial mindset as existing on a cognitive spectrum in which its core attributes are relatively static across all disciplines. This notion suggests that entrepreneurial mindset is domain-general and all highly entrepreneurial people take calculated risks, lead, and exhibit other related traits that do not depend on the disciplinary affordances [58]. The contraposition that entrepreneurial mindset is constructed and contextualized within specific domains would mean that particular entrepreneurship programs should be informed by disciplinary rules and epistemologies [59].

Most engineering education scholars have specifically advocated for a discipline specific curriculum for teaching entrepreneurship $[4,60,61]$. This approach makes it relevant to understand the entrepreneurial mindsets and skills in the engineering domain in order to provide the most pertinent curricular scaffolding to relevant and specific educational programs. Kriewall and Mekemson [39] maintain that entrepreneurship in engineering education should include the technical fundamentals that characterize the discipline. Alternatively, an integrationist approach suggests that some components of the entrepreneurial mindset are considered domain-general while others are domain-specific [56]. This has been the case in studies of creativity [57] or studies on epistemological beliefs [62]. There is still a gap to this approach in identifying which dimensions/characteristics are domain general and which are domain specific. Some attempts have been pursued to describe the specific translation of entrepreneurship by delimiting research and application to an independent setting (e.g., engineering education). Most of these attempts have been indirectly guided by the Three C's frameworks associated with KEEN [20,39]. KEEN schools have adopted this framework [63] as a useful tool for practitioners, but the framework does not consider new theories or questions on the entrepreneurial learning from contemporary theoretical debates and research grounding [6]. The 3 C's framework works as a ready-to-adopt methodology that is presented in a confirmatory position. This format is beneficial to engineering programs that need a starting point, but not as a guideline for basic research. We believe that entrepreneurship education in undergraduate engineering programs has reached a critical juncture that requires more scholarly approaches to defining the entrepreneurial mindset.

\subsection{Challenge 05: Entrepreneurship and Educational Theory}

The rapid growth of entrepreneurial programs has not always involved a profound understanding of the educational process behind entrepreneurship education [18]. Morris and Ligouri [18] argue that more research is needed to address several key research questions related to education: How is entrepreneurship taught? What contents should be imparted to students? How should we evaluate results? Mäkimurto-Koivumaa and Belt [64] sought to answer these first two questions by proposing a competency model for entrepreneurship education in non-business programs. The model states that a foundation of "professional knowledge" translates into "business knowledge" and results in competencies related to "personal growth", which surpass the traditional educational model for engineering education based primarily on technical competences. According to De Graaf and Ravenstein [65], for new engineers adopting an entrepreneurial mindset, it is important to achieve a balance between increased technical knowledge and broad general competencies. Other scholars assert that the entrepreneurial mindset seems to be connected to cognitive strategies [29] and general competencies [64], more so than to specific knowledge. The opportunity for integrating these perspectives exists, but most entrepreneurial programs have consistently disregarded the evidence, models, and theory from the field of education that are linked to entrepreneurship education [66].

Morris and Ligouri's [18] perspective helps to frame the entrepreneurship education discussion in the immediate context in which it is situated: educational theory. This is especially important when considering prior suggestions that entrepreneurship education has lacked legitimacy in the context of higher education [67]. According to Hindle [67], entrepreneurship education has for a long period of time been very nascent, with not enough theorization and incipient research programs. Many researchers have since sought to incorporate concepts from educational theory and psychology. This has not resulted in publications with deeper philosophical, methodological, and theoretical underpinnings [25]. 
Most research publications have been descriptive in nature, didactic in orientation, and lack the explanatory power of general theories. On the other hand, the philosophy of entrepreneurship can also impact the practice of education in general. According to Kyrö [68], integrated discussions of entrepreneurship studies and educational theory and research would impact education itself by making our teaching and learning methods more entrepreneurial. For Kyrö [68], entrepreneurship brings together action-orientation, autonomy, and the interplay between risk and responsibility, to the center of the learning process, which may be a useful approach for all aspects of teaching.

Engineering entrepreneurship education often lacks research regarding the pedagogical and learning underpinnings of education theory [24]. As discussed in Section 3.1, engineering entrepreneurship has mostly been focused on teaching business tools [69]. Engineering entrepreneurship education has increasingly emphasized the need for educational models that fit the hands-on nature of engineering learning [70]. This is translated into preferences for project-based learning, learning by doing, team work, interdisciplinarity, and project engagement [24]. Engineering education fits with the action-oriented nature of entrepreneurship [68], but there is still the challenge of conceptualizing this relationship between engineering and entrepreneurship education under comprehensive and explanatory general theories of learning [25].

\subsection{Challenge 06: Loss of Specificity and Assessment in Entrepreneurship}

Assessing entrepreneurship and related entrepreneurial characteristics can be challenging, particularly if attempting to measure something embedded within the mind. Zappe [5] (p. 4) argues that the definition and assessment of the entrepreneurial mindsets and skills in educational programs in engineering are often treated as a sort of omnibus construct, or a "construct that is likely comprised of multiple subconstructs, making its operationalization and measurement more difficult." The term "mindset" is often used even though items are designed to measure entrepreneurially-related behaviors. Zappe [5] examines the survey developed by Li, Harichandran, Carnasciali, Erdil, and Nocito-Gobelin in 2016 as an example of an entrepreneurial mindset instrument. The survey includes 29 prompts based on approximately ten distinct factors. She concludes that there is a threat in "the oversimplification of entrepreneurial mindset into a scale measuring complex sub constructs, each of which being measured by just a few items" (p. 7).

Brunhaver, Bekki, Carberry, London and McKenna [71] similarly developed a survey designed to measure curiosity, creating value, and connections (Three C's). A set of 60 items were designed based on London et al.'s [20] exploration and operationalization of the Three C's framework within entrepreneurship, curiosity, value, and connections literature. Exploratory factor analysis results of items designed to align with the operationalized framework did not align well with the three proposed components of entrepreneurial mindset. The seven resulting factors consisting of 34 items were examined to identify embedded themes. Two emergent themes were represented by only two items, which is conceptually problematic when assessing complex constructs like altruism and empathy. The works of London et al. [20] and Brunhaver et al. [71] show that the use of an institutional framework that is not sustained in evidence generates conceptual and statistical challenges when justifying the content validity of the assessment results.

One additional instrument of note is that of Davis, Hall and Mayer [37]. This extensive survey used 115 items organized by 14 factors to assess the entrepreneurial mindset as a set of both, personality traits and skills. The approach was very comprehensive and thorough, although potentially plagued by "survey response fatigue" [72]. A major conceptual concern was the assumption that entrepreneurial mindset is seen as a domain-general phenomenon, within which other constructs like creativity or traditional personality traits are grouped. This illustrates an example of being methodologically overly ambitious. There is a clear need, based on the whole of these efforts, to construct a focused assessment of the entrepreneurial mindset, accounting for both its domain-general and domain-specific components. 


\subsection{Challenge 07: A Value-Driven Entrepreneurship in Research and Practice}

Scholars and practitioners should not only be concerned with what the entrepreneurial mindsets and skills are as well as what they ought to be. Entrepreneurship studies have not experienced a normative turn per se, but there is a growing trend of counter-culture or value-driven entrepreneurship practice and research. Critical studies of entrepreneurship, often derived from Critical Management Studies (CMS), have gained attention in recent years [73]. For instance, although entrepreneurship studies have not usually explored the dimension of ethics in depth, there is a growing number of articles addressing the ethics of entrepreneurship [74]. More conventional and business-driven studies of entrepreneurship have engaged with ethics through the idea of responsible entrepreneurship [75] or social entrepreneurship [76].

Ethics also has an affective and socio-cognitive correlation with empathy and prosocial behavior, both of which help to unpack the idea of "ethical competence" [77]. Empathy is the capacity to feel, share and understand another person's state of mind and emotions. It is usually thought of as the ability to "put oneself into another's shoes" [78]. Prosocial behavior can be defined as "a broad category of acts that are defined by some significant segment of society and/or one's social group as generally beneficial to other people" (p.366) [79]. Dunfield [80] separates prosocial behavior into three distinct actions: helping, sharing and comforting others. Empathy, and to a lesser extent, prosocial behavior has been considered fundamental to the entrepreneurial mindset $[81,82]$.

It is imperative as researchers to remember that empathy and prosocial behavior are easily manipulated and biased. For instance, as evidence pointed out by Bloom [83] shows, while empathy can motivate kindness, it can also motivate cruelty and aggression (empathy can motivate us to give someone unfair advantages, or to resent those who compete with them) and lead to burnout and exhaustion. Without critical and philosophical reflection, empathy and prosocial behavior do not assure morally justified outcomes, as it is also the case for social and responsible entrepreneurship. As Chell, Spencer, Perrini and Harris [84] note, social is not the same as ethical. As they argue: "There is a presumption that because something is socially-oriented, motivation is likely to be ethically sound; that it is principled, morally justified and ethically legitimate." (p.621) [84]. By extension, an ethical reflection is a more profound endeavor than seeking to solve social issues. A systematic ethical reflection demands a sincere questioning about the value of entrepreneurship itself. Under what conditions is entrepreneurship just and legitimate? What should be the values driving entrepreneurship? What ought to be entrepreneurship education? The first question is mostly related to issues of distributive justice. The second one (and most of the times, the least explored in literature) is related to axiology. The last question is one of deontology. We discuss these last two themes-axiology and deontology-below.

Axiology is the branch of philosophy that is concerned with values and worth. One might assume that these features might strongly coincide with entrepreneurship education, in the sense that entrepreneurship has classically been concerned with the creation of value. Nonetheless, axiology has been discussed in entrepreneurship education by only exceptional authors, most notably by Paula Kyrö [68,85]. Another of the few examples is Hurst [86], who developed a measurement to assess the axiology of entrepreneurship. Deontology, on the other hand, is the branch of philosophy concerned with duty and the intrinsic goodness of an action. Not many publications explicitly talk about deontology, but there is an argument to be made about the deontological presuppositions of responsible and social entrepreneurship debates. There should be a larger incorporation of these concepts in entrepreneurship studies.

The implications of these discussions for engineering entrepreneurship education are multiple. Since technology and science have a big role in the discipline, STS debates should be more closely aligned with engineering entrepreneurship than other disciplines. Scholars and practitioners of engineering entrepreneurship education should attend to trends in STS because they will impact how engineering skills and products are acknowledged by society. Entrepreneurship conceptualization and assessments in engineering that are interested in integrating ethics should debate and educate on the values that undergird (axiology) and duties that are specific to engineering entrepreneurship 
(deontology). This is particularly crucial when we consider that engineering design is often viewed as a key mechanism "in turning dreams into reality" and thus involves some major ethical considerations and responsibilities [87]. Engineers are called to act with empathy and care [88], but also with some serious philosophical considerations. A culture of entrepreneurship is based on empowerment, autonomy and responsibility to face social challenges [89]. A world without systematic ethics and values can lead to engineering solutions with disastrous results.

\section{Discussion}

Throughout this conceptual review, we have discussed seven key challenges to consider in an effort to produce a more comprehensive, socially engaged, and integrated vision for both entrepreneurship education and its learning outcomes (e.g., entrepreneurial mindsets and skills), specially for the context of engineering education. We do not seek to provide answers to these challenges, but to shed a light on fundamental considerations that practitioners and researchers should keep in mind when designing entrepreneurship education practices and assessing and conceptualizing the entrepreneurial mindsets and skills, particularly in the context of engineering. Overall, we observe that the concept of entrepreneurship (both as an education practice and as a learning outcome) is complex and is in a state of flux. Discussions around these issues point to the theoretical, ethical, methodological and practical nuances that should be kept in mind while researching or practicing entrepreneurship in higher education.

The implications of this article are twofold:

First, we synthesized key discussions around the educational practice and learning outcomes of entrepreneurship in a way that enables the emergence of research gaps to be addressed in the future. We also examined and enriched those challenges by incorporating conceptual elements from diverse disciplines such as psychology, sociology and philosophy. Figure 1 shows emerging research questions identified for each of the challenges.

\begin{tabular}{|c|c|c|}
\hline & & EMERGING RESEARCH QUESTIONS \\
\hline $\mathrm{CHOI}$ & $\begin{array}{l}\text { The economic reification } \\
\text { of entrepreneurship }\end{array}$ & $\begin{array}{l}\text { How to define entrepreneurial "skills or mindset" } \\
\text { beyond venture creation? }\end{array}$ \\
\hline $\mathrm{CHO} 2$ & $\begin{array}{l}\text { Entrepreneurship, "to } \\
\text { be or not to be" }\end{array}$ & $\begin{array}{l}\text { How to conceptualize entrepreneurial "skills or } \\
\text { mindset" as a spectrum where diversity is visible? }\end{array}$ \\
\hline $\mathrm{CHO} 3$ & $\begin{array}{l}\text { The decontextualization } \\
\text { of entrepreneurship }\end{array}$ & $\begin{array}{l}\text { How to conceptualize the relationship between } \\
\text { entrepreneurship and its context? }\end{array}$ \\
\hline $\mathrm{CHO} 4$ & $\begin{array}{l}\text { The domain specificity } \\
\text { of entrepreneurship }\end{array}$ & $\begin{array}{l}\text { What elements of the entrepreneurial "skills or } \\
\text { mindset" are domain specific and domain general? }\end{array}$ \\
\hline CHO5 & $\begin{array}{l}\text { Entrepreneurship and } \\
\text { educational theory }\end{array}$ & $\begin{array}{l}\text { How can entrepreneurship education incorporate } \\
\text { educational research and theory? }\end{array}$ \\
\hline CHO6 & $\begin{array}{l}\text { Loss of specificity and } \\
\text { assessment in } \\
\text { entrepreneurship }\end{array}$ & $\begin{array}{l}\text { How to assess entrepreneurial "skills or mindset" } \\
\text { in inclusive terms without losing conceptual } \\
\text { specificity? }\end{array}$ \\
\hline $\mathrm{CHO7}$ & $\begin{array}{l}\text { A value-driven } \\
\text { entrepreneurship in } \\
\text { research and practice }\end{array}$ & $\begin{array}{l}\text { How to incorporate ethics and values in entrepre- } \\
\text { neurship research and practice? }\end{array}$ \\
\hline
\end{tabular}

Figure 1. Emerging research questions for each of the challenges. 
This list of research questions does not exhaust the nuances described in each challenge, but they do capture its essence. We assert that the exploration of each of these research questions could lead to a more robust understanding of entrepreneurship in the context of teaching and learning engineering. As stated throughout this article, some of these challenges relate to the educational practices and assessment methods that conform entrepreneurship education (e.g., $\mathrm{CH02,} \mathrm{CH0} 5$ and $\mathrm{CH06)}$, while others relate to the conceptualization of the learning outcomes of entrepreneurship (e.g., $\mathrm{CH} 01, \mathrm{CH} 03, \mathrm{CH} 04$ and $\mathrm{CH} 07)$.

Secondly, this review contributes to entrepreneurship and engineering educators seeking to enhance their practice by deepening their understanding on the nature and uses of entrepreneurship in higher education. Our review shows that the current practice of entrepreneurship education incurs sometimes in a reductionist (e.g., $\mathrm{CH01}$ and $\mathrm{CH02}$ ) and a decontextualized (e.g., $\mathrm{CH03}$ and $\mathrm{CH04}$ ) view of entrepreneurship that may lack the theoretical (CH05), methodological (CH06) and ethical (CH07) aspects needed to re-imagine this phenomenon for the future.

These challenges show three practical dimensions on issues to be considered in a re-imagined definition of entrepreneurship for engineering education. These dimensions are portrayed in Figure 2, a conceptual framework where the definition of entrepreneurship looks to be, act and involve. These dimensions imply change in the ways we conceptualize the act of being an entrepreneur in higher education in engineering. This definition might only see the light once the challenges, posed in this article, are tackled.

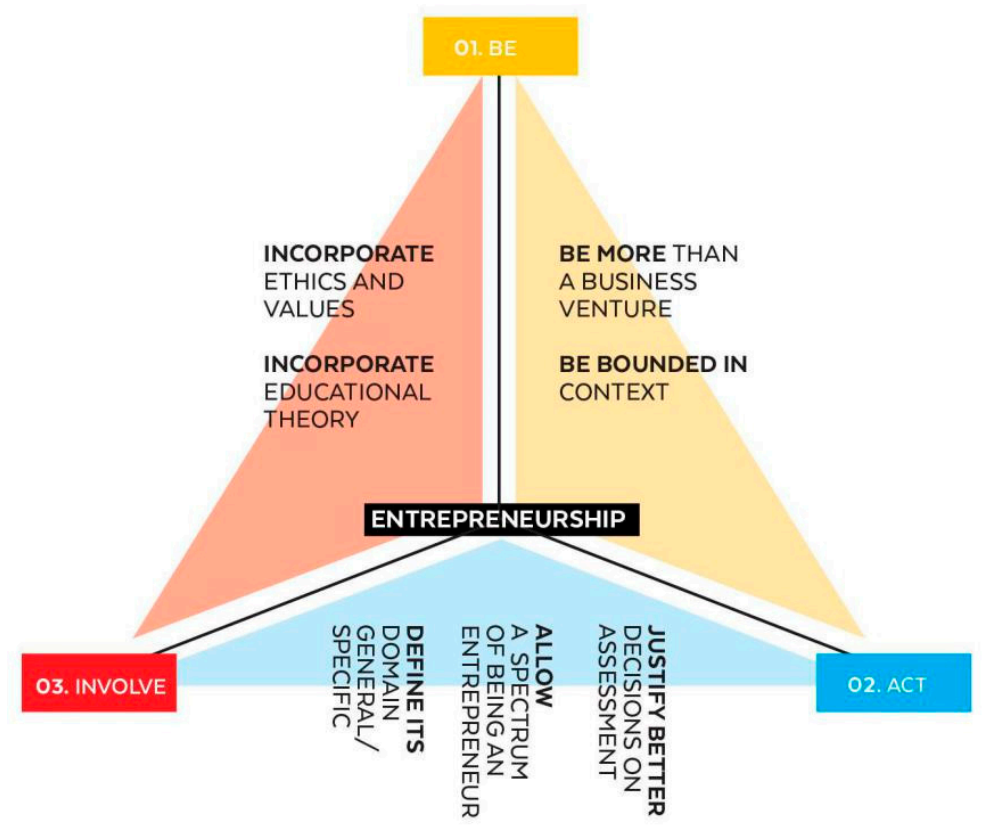

Figure 2. Practical framework for a redefinition of entrepreneurship.

Entrepreneurship education research can facilitate multi-disciplinary collaboration. This article suggests means of collaboration, as it draws from different literature in sociology, psychology, philosophy, business, and engineering education. It is our assertion that entrepreneurship education leads to impact that extends beyond business creation, and also promotes skills that are very useful at every professional level, such as: empathy, learning autonomy, self-regulated learning, and embracing risk within others. We suggest that this perspective can directly affect the assessment of the entrepreneurial mindset in engineering education, and in policies related to entrepreneurship in engineering.

Finally, the future steps of this project are to evaluate current entrepreneurship education programs and policies based on these proposed challenges. This critical examination will illuminate whether the challenges described in the literature resonate or not with the praxis of entrepreneurship education. 
Additionally, we seek to use these challenges as guiding principles to create our own assessment methods in a way that satisfies the theoretical, methodological and ethical concerns that have been presented in this article.

Author Contributions: Conceptualization, C.M. and J.G.; Methodology C.M. and J.G.; writing-original draft preparation, C.M., J.G., B.B.; writing-review and editing, C.M., B.B., and A.C.; visualization, C.M. Funding Acquisition C.M. and B.B. All authors have read and agreed to the published version of the manuscript.

Funding: This ongoing research project has received funding from the project "A Research Network on Engineering Education in Entrepreneurship" Open Seedfund Ingeniería UC from Corfo Engineering 2030. CORFO14ENi2-26862.

Conflicts of Interest: The authors declare no conflict of interest.

\section{References}

1. Oswald Beiler, M.R. Integrating Innovation and Entrepreneurship Principles into the Civil Engineering Curriculum. J. Prof. Issues Eng. Educ. Pract. 2015, 141, 04014014. [CrossRef]

2. Winters, J.V. STEM graduates, human capital externalities, and wages in the US. Reg. Sci. Urban Econ. 2014, 48, 190-198. [CrossRef]

3. Weilerstein, P.; Byers, T. Entrepreneurship and Innovation in Engineering Education. Adv. Eng. Educ. 2016, 1, 1-3.

4. Huang-Saad, A.Y.; Morton, C.S.; Libarkin, J.C. Entrepreneurship Assessment in Higher Education: A Research Review for Engineering Education Researchers. J. Eng. Educ. 2018, 107, 263-290. [CrossRef]

5. Zappe, S.E. Avoiding construct confusion: An attribute-focused approach to assessing entrepreneurial mindset. Adv. Eng. Educ. 2018, 7, n1.

6. Huang-Saad, A.; Bodnar, C.; Carberry, A. Examining Current Practice in Engineering Entrepreneurship Education. Entrep. Educ. Pedagog. 2020, 3, 4-13. [CrossRef]

7. Grinter, L.E. Report on evaluation of engineering education. Eng. Educ. 1955, 45, 25-60.

8. Dym, C.L.; Agogino, A.M.; Eris, O.; Frey, D.D.; Leifer, L.J. Engineering Design Thinking, Teaching, and Learning. J. Eng. Educ. 2005, 94, 103-120. [CrossRef]

9. Prados, J.W.; Peterson, G.D.; Lattuca, L.R. Quality Assurance of Engineering Education through Accreditation: The Impact of Engineering Criteria 2000 and Its Global Influence. J. Eng. Educ. 2005, 94, 165-184. [CrossRef]

10. Accreditation Board for Engineering and Technology (ABET). About ABET. 2019. Available online: https://www.abet.org/about-abet/ (accessed on 12 October 2019).

11. Brannan, K.P.; Dion, T.R.; Fallon, D.J. ABET Engineering Criteria 2000: Assessment of Classroom Instruction. In 1999 ASEE Southeastern Section Conference; ASEE: Gainesville, FL, USA, 1999.

12. Hilliger, I.; Miranda, C.; Pérez-Sanagustín, M.; De La Vega, M. Does the revision of ABET student outcomes include the competencies required to succeed in start-ups and entrepreneurial companies? In ASEE Annual Conference and Exposition, Conference Proceedings; ASEE: Columbus, OS, USA, 2017.

13. Aparicio, G.; Iturralde, T.; Maseda, A. Conceptual structure and perspectives on entrepreneurship education research: A bibliometric review. Eur. Res. Manag. Bus. Econ. 2019. [CrossRef]

14. Celis, S.; Hilliger, I. Redesigning Engineering Education in Chile: How Selective Institutions Respond to an Ambitious National Reform. In ASEE Annual Conference; ASEE: New Orleans, LA, USA, 2016.

15. European Commission. Entrepreneurship 2020 Action Plan; European Commission: Brussels, Belgium, 2013.

16. Fretschner, M.; Weber, S. Measuring and understanding the effects of entrepreneurial awareness education. J. Small Bus. Manag. 2013, 51, 410-428. [CrossRef]

17. Shartrand, A.; Weilerstein, P.; Besterfield-Sacre, M.; Golding, K. Technology entrepreneurship programs in U.S. engineering schools: Course and program characteristics at the undergraduate level. In Proceedings of the American Society for Engineering Education, Louisville, KY, USA, 29 June 2010.

18. Morris, M.H.; Liguori, E.W. Preface: Teaching reason and the unreasonable. In Annals of Entrepreneurship Education and Pedagogy; Morris, M.H., Liguori, E.W., Eds.; Edward Elgar Publishing: Northam, MA, USA, 2016.

19. Duval-Couetil, N.; Kisenwether, E.; Tranquillo, J.; Wheadon, J. Exploring the intersection of entrepreneurship education and ABET accreditation criteria. J. Eng. Entrep. 2015, 6, 44-57. [CrossRef] 
20. London, J.S.; Bekki, J.M.; Brunhaver, S.R.; Carberry, A.R.; McKenna, A.F. A Framework for Entrepreneurial Mindsets and Behaviors in Undergraduate Engineering Students: Operationalizing the Kern Family Foundation's "3Cs". Adv. Eng. Educ. 2018, 7, n1.

21. Commarmond, I. Pursuit of a Better Understanding of and Measure for Entrepreneurial Mindset; Cape Town, South Africa, 2017. Available online: https://www.allangrayorbis.org/wp-content/uploads/2017/10/Literaturereview-1.pdf (accessed on 28 October 2020).

22. Duval-Couetil, N.; Reed-Rhoads, T.; Haghighi, S. Engineering students and entrepreneurship education: Involvement, attitudes and outcomes. Int. J. Eng. Educ. 2012, 28, 10.

23. Ferrari, R. Writing narrative style literature reviews. Med. Writ. 2015, 24, 230-235. [CrossRef]

24. Fayolle, A.; Lamine, W.; Mian, S.; Phan, P. Effective models of science, technology and engineering entrepreneurship education: Current and future research. J. Technol. Transfer. 2020. [CrossRef]

25. Higgins, D.; Refai, D.; Keita, D. Focus point: The need for alternative insight into the entrepreneurial education paradigm. J. Small Bus. Entrep. 2019, 31, 225-242. [CrossRef]

26. Green, B.N.; Johnson, C.D.; Adams, A. Writing narrative literature reviews for peer-reviewed journals: Secrets of the trade. J. Chiropr. Med. 2006, 5, 101-117. [CrossRef]

27. Pittaway, L.; Cope, J. Entrepreneurship Education a Systematic Review of the Evidence. Int. Small Bus. J. 2007, 25, 479-510. [CrossRef]

28. Boyd, N.G.; Vozikis, G.S. The Influence of Self-Efficacy on the Development of Entrepreneurial Intentions and Actions. Entrep. Theory Pract. 1994, 18, 4. [CrossRef]

29. Haynie, J.M.; Shepherd, D.; Mosakowski, E.; Earley, P.C. A situated metacognitive model of the entrepreneurial mindset. J. Bus. Ventur. 2010, 25, 217-229. [CrossRef]

30. Anderson, A.R. The economic reification of entrepreneurship. In Rethinking Entrepreneurship: Debating Research Orientations; Fayolle, A., Riot, P., Eds.; Routledge Press: London, UK, 2015; pp. 44-56.

31. Lundmark, E.; Krzeminska, A.; Shepherd, D.A. Images of entrepreneurship: Exploring root metaphors and expanding upon them. Entrep. Theory Pract. 2019, 43, 138-170. [CrossRef]

32. Hjorth, D.; Bjerke, B. Public entrepreneurship: Moving from social/consumer to public/citizen. In Entrepreneurship as Social Change: A Third Movements in Entrepreneurship; Cheltenham, Steyaert, C., Hjorth, D., Eds.; Edward Elgar: Cheltenham, UK, 2006; pp. 97-120.

33. Sarasvathy, S.D.; Venkataraman, S. Entrepreneurship as method: Open questions for an entrepreneurial future. Entrep. Theory Pract. 2011, 35, 113-135. [CrossRef]

34. Gartner, W.B. Entrepreneurial narrative and a science of the imagination. J. Bus. Ventur. 2007, 22, 613-627. [CrossRef]

35. Günzel-Jensen, F.; Moberg, K.; Mauer, R.; Neergaard, H. Self-Efficacy and the Entrepreneurial Mindset Revisited. In Revisiting the Entrepreneurial Mind; Springer: Cham, Switzerland, 2017; pp. 319-335. [CrossRef]

36. Da Silva, G.B.; Costa, H.C.; De Barros, M.D. Entrepreneurship in engineering education: A literature review. Int. J. Eng. Educ. 2015, 3, 1701-1710.

37. Davis, M.H.; Hall, J.A.; Mayer, P.S. Developing a new measure of entrepreneurial mindset: Reliability, validity, and implications for practitioners. Consult. Psychol. J. Pract. Res. 2016, 68, 21. [CrossRef]

38. Purzer, S.; Fila, N.; Nataraja, K. Evaluation of Current Assessment Methods in Engineering Entrepreneurship Education. Adv. Eng. Educ. (Winter) 2016, 5, n1.

39. Kriewall, T.J.; Mekemson, K. Instilling the entrepreneurial mindset into engineering undergraduates. J. Eng. Entrep. 2010, 1, 5-19.

40. Bourdieu, P. Distinction; Routledge: London, UK, 1986.

41. Bosman, L.; Fernhaber, S. Defining the entrepreneurial mindset. In Teaching the Entrepreneurial Mindset to Engineers; Bosman, L., Fernhaber, S., Eds.; Springer International: Heidelberg, Germany, 2018; pp. 7-14.

42. Welter, F.; Baker, T.; Wirsching, K. Three waves and counting: The rising tide of contextualization in entrepreneurship research. Small Bus. Econ. 2019, 52, 319-330. [CrossRef]

43. Lounsbury, M.; Gehman, J.; Ann Glynn, M. Beyond Homo Entrepreneurus: Judgment and the Theory of Cultural Entrepreneurship. J. Manag. Stud. 2019, 56. [CrossRef]

44. Chowdhury, S. Demographic diversity for building an effective entrepreneurial team: Is it important? J. Bus. Ventur. 2005, 20, 727-746. [CrossRef]

45. Patriotta, G.; Siegel, D. The Context of Entrepreneurship. J. Manag. Stud. 2019, 56. [CrossRef] 
46. Welter, F. Contextualizing Entrepreneurship-Conceptual Challenges and Ways Forward. Entrep. Theory Pract. 2011, 35, 165-184. [CrossRef]

47. Walter, S.G.; Dohse, D. Why mode and regional context matter for entrepreneurship education. Entrep. Reg. Dev. Routledge 2012, 24, 807-835. [CrossRef]

48. Gibson, J. A theory of affordances. In Perceiving, Acting and Knowing: Toward an Ecological Psychology; Shaw, R., Bransford, J., Eds.; Lawrence Erlbaum: Hillsdale, NJ, USA, 1977; pp. 67-82.

49. Thomassen, M.L.; Williams Middleton, K.; Ramsgaard, M.B.; Neergaard, H.; Warren, L. Conceptualizing context in entrepreneurship education: A literature review. Int. J. Entrep. Behav. Res. 2019. [CrossRef]

50. Bronfenbrenner, U. The Ecology of Human Development: Experiments by Nature and Design; Harvard University Press: Cambridge, MA, USA, 1979.

51. Rowlands, M. The Body in Mind: Understanding Cognitive Processes; Cambridge University Press: Cambridge, UK, 1999.

52. Clark, A.; Chalmers, D. The extended mind. Analysis 1998, 58, 7-19. [CrossRef]

53. Clark, A. Embodied, Situated, and Distributed Cognition. In A Companion to Cognitive Science; Blackwell Publishing Ltd: Oxford, UK, 2017; pp. 506-517.

54. Dew, N.; Grichnik, D.; Mayer-Haug, K.; Read, S.; Brinckmann, J. Situated Entrepreneurial Cognition. Int. J. Manag. Rev. 2015, 17, 143-164. [CrossRef]

55. Sassetti, S.; Marzi, G.; Cavaliere, V.; Ciappei, C. Entrepreneurial Cognition and Socially Situated Approach: A Systematic and Bibliometric Analysis. Scientometrics 2018, 116, 1675-1718. [CrossRef]

56. Nambisan, S. Entrepreneurship perspectives: An introduction. In Embracing Entrepreneurship Across Disciplines; Nambisan, S., Ed.; Edward Elgar Publishing: Cheltenham, UK, 2015. [CrossRef]

57. Kaufman, J. Creativity 101, 2nd ed.; Springer: New York, NY, USA, 2016.

58. Nadelson, L.S.; Palmer, A.D.; Benton, T.; Basnet, R.; Bissonnette, M.; Cantwell, L.; Jouflas, G.; Elliot, E.; Fromm, M.; Lanci, S. Developing Next Generation of Innovators: Teaching Entrepreneurial Mindset Elements across Disciplines. Int. J. High Educ. 2018, 7, 114-126. [CrossRef]

59. DeNardin, T.; Gardner, J.; Gardner, T.; Stammerjohan, C.A.; Stammerjohan, W.W.; Winkel, M. Creativity and Entrepreneurship: An Exploratory Multiple Case Study of What Entrepreneurs Think. Small Bus. Inst. J. 2019, 19, 18-38.

60. Byers, T.; Seelig, T.; Sheppard, S.; Weilerstein, P. Entrepreneurship: Its Role in Engineering Education. Bridge 2013, 43, 35-40.

61. Gilmartin, S.K.; Chen, H.L.; Estrada, C. Investigating entrepreneurship program models in undergraduate engineering education. Int. J. Eng. Educ. 2016, 32, 2048-2065.

62. Barzilai, S.; Eshet-Alkalai, Y. The role of epistemic perspectives in comprehension of multiple author viewpoints. Learn. Instr. 2015, 36, 86-103. [CrossRef]

63. Rae, D.; Melton, D.E. Developing an Entrepreneurial Mindset in US Engineering Education: An International View of the KEEN Project. J. Eng. Entrep. 2017, 7, 3.

64. Mäkimurto-Koivumaa, S.; Belt, P. About, for, in or through entrepreneurship in engineering education. Eur. J. Eng. Educ. 2016, 41, 512-529. [CrossRef]

65. De Graaff, E.; Ravesteijn, W. Training Complete Engineers: Global Enterprise and Engineering Education. Eur. J. Eng. Educ. 2001, 26, 419-427. [CrossRef]

66. Robinson, S.; Neergaard, H.; Tanggaard, L.; Krueger, N.F. New horizons in entrepreneurship education: From teacher-led to student-centered learning. Educ. Train. 2016, 58, 661-683. [CrossRef]

67. Hindle, K. Teaching Entrepreneurship at University: From the Wrong Building to the Right Philosophy. In Handbook of Research in Entrepreneurship Education; Edward Elgar Publishing: Cheltenham, UK, 2007; pp. 104-126.

68. Kyrö, P. The conceptual contribution of education to research on entrepreneurship education. In A Research Agenda for Entrepreneurship Education; Alain, E., Ed.; Edward Elgar Publishing: Cheltenham, UK, 2018; pp. 164-186.

69. Besterfield-Sacre, M.; Zappe, S.; Shartrand, A.; Hochstedt, K. Faculty and student perceptions of the content of entrepreneurship courses in engineering education. Adv. Eng. Educ. 2016, 5, 1-27.

70. Linton, J.D.; $\mathrm{Xu}, \mathrm{W}$. Research on science and technological entrepreneurship education: What needs to happen next? J. Technol. Transf. 2020. [CrossRef] 
71. Brunhaver, S.R.; Bekki, J.M.; Carberry, A.R.; London, J.S.; McKenna, A.F. Development of the Engineering Student Entrepreneurial Mindset Assessment (ESEMA). Adv. Eng. Educ. 2018, 7, 12.

72. Egleston, B.L.; Miller, S.M.; Meropol, N.J. The impact of misclassification due to survey response fatigue on estimation and identifiability of treatment effects. Stat. Med. 2011, 30, 3560-3572. [CrossRef] [PubMed]

73. Germain, O.; Jacquemin, A. Positioning Entrepreneurship Studies between Critique and Affirmation. Rev. l'Entrepreneuriat 2017, 16, 55. [CrossRef]

74. Dey, P.; Steyaert, C. Tracing and Theorising Ethics in Entrepreneurship. In The Routledge Companion to Ethics, Politics and Organizations; Pullen, A., Rhodes, C., Eds.; Routledge: London, UK, 2015; pp. 103-118.

75. Tiba, S.; van Rijnsoever, F.J.; Hekkert, M.P. Firms with Benefits: A Systematic Review of Responsible Entrepreneurship and Corporate Social Responsibility Literature. Corp. Soc. Responsib. Environ. Manag. 2019, 26, 265-284. [CrossRef]

76. Phillips, W.; Lee, H.; Ghobadian, A.; O’Regan, N.; James, P. Social Innovation and Social Entrepreneurship. Gr. Organ. Manag. 2015, 40, 428-461. [CrossRef]

77. Pohling, R.; Bzdok, D.; Eigenstetter, M.; Stumpf, S.; Strobel, A. What is Ethical Competence? The Role of Empathy, Personal Values, and the Five-Factor Model of Personality in Ethical Decision-Making. J. Bus. Ethics 2016, 137, 449-474. [CrossRef]

78. Ioannidou, F.; Konstantikaki, V. Empathy and emotional intelligence: What is it really about? Int. J. Caring Sci. 2008, 1, 118-123.

79. Penner, L.A.; Dovidio, J.F.; Piliavin, J.A.; Schroeder, D.A. Prosocial Behavior: Multilevel Perspectives. Annu. Rev. Psychol. 2005, 56, 365-392. [CrossRef] [PubMed]

80. Dunfield, K.A. A construct divided: Prosocial behavior as helping, sharing, and comforting subtypes. Front. Psychol. 2014, 5. [CrossRef]

81. Korte, R.; Smith, K.A.; Li, C.Q. The Role of Empathy in Entrepreneurship: A Core Competency of the Entrepreneurial Mindset. Adv. Eng. Educ. 2018, 7, n1.

82. Shepherd, D.A. Party On! A call for entrepreneurship research that is more interactive, activity based, cognitively hot, compassionate, and prosocial. J. Bus. Ventur. 2015, 30, 489-507. [CrossRef]

83. Bloom, P. Empathy and Its Discontents. Trends Cogn. Sci. 2017, 21, 24-31. [CrossRef] [PubMed]

84. Chell, E.; Spence, L.J.; Perrini, F.; Harris, J.D. Social Entrepreneurship and Business Ethics: Does Social Equal Ethical? J. Bus. Ethics 2016, 133, 619-625. [CrossRef]

85. Kyro, P. The Continental and Anglo-American Approaches to Entrepreneurship Education: Differences and Bridges. In International Entrepreneurship Education: Issues and Newness; Fayolle, A., Klandt, H., Eds.; Edward Elgar Publishing Limited: Cheltenham, UK, 2006; pp. 93-111.

86. Hurst, C.G. An Axiological Measure of Entrepreneurial Cognition. Int. J. Entrep. Behav. Res. 2019, 25, 394-412. [CrossRef]

87. Foley, R.; Gibbs, B. Connecting Engineering Processes and Responsible Innovation: A Response to Macro-Ethical Challenges. Eng. Stud. 2019, 11, 9-33. [CrossRef]

88. Hess, J.L.; Strobel, J.; Pan, R. Voices from the workplace: Practitioners' perspectives on the role of empathy and care within engineering. Eng. Stud. 2016, 8, 212-242. [CrossRef]

89. Lindner, J. Entrepreneurship Education for a Sustainable Future. Discourse Commun. Sustain. Educ. 2018, 9, 115-127. [CrossRef]

Publisher's Note: MDPI stays neutral with regard to jurisdictional claims in published maps and institutional affiliations.

(C) 2020 by the authors. Licensee MDPI, Basel, Switzerland. This article is an open access article distributed under the terms and conditions of the Creative Commons Attribution (CC BY) license (http://creativecommons.org/licenses/by/4.0/). 